\title{
COST MANAGEMENT IN HIGHER EDUCATION FEDERAL INSTITUTIONS IN BRAZIL: A MANAGEMENT REPORT ANALYSIS
}

\author{
Samuel Cavalcante Mota, Antonio Rafael Valério de Oliveira, \\ Naiara Taise Sousa Nunes and Hugo Santana de Figueirêdo Junior \\ Universidade Federal do Ceará \\ Av. da Universidade, 2486 - Benfica - CEP 60020-180 - Fortaleza-CE, Brazil
}

\begin{abstract}
Cost management in the public sector has proved to be a difficult task, especially in higher education institutions. The purpose of this research is to investigate the recent experiences of cost management in Brazilian federal universities, under a new scenario of performance requirements and availability of compulsory functionalities for cost assessment in the Integrated System for Financial Management (SIAFI) of the Federal Government. This is a qualitative research, conducted through content analysis of management reports provided by the existing Brazilian federal universities, with the assistance of the software Atlas.ti. The analysis reveals that, out of the studied federal universities, $40 \%$ do not utilise any cost assessment system and that the integration barriers with supporting information systems often serve as excuses not to implement cost management. The mandatory insertion of information on cost centres within SIAFI, as well as legal requirements are the main motivations for federal universities to conduct cost assessment. The presentation of cost information just referring to the costs website of the federal government was a recurrent approach in the federal universities' management reports. For benchmarking, there is a clear need to standardize a cost assessment methodology for Higher Education Federal Institutions (HEFI) and to train the universities' staff in the application of such a methodology. From this study, it is possible to realise the magnitude of the challenge still ahead for the HEFI to adapt to the financially constrained higher education scenario in Brazil.
\end{abstract}

\section{KEYWORDS}

Costs, Public Sector, Federal Universities, Decision Support Systems

\section{INTRODUCTION}

Higher Education Federal Institutions (HEFI) in Brazil have lately faced financial constraints that represent a threat to the continuity of their services. Since they are supported almost entirely by resources from the national treasury, the recent Brazilian economic crisis has imposed great challenges to the HEFI, as the pressure for cost control and efficiency increases.

The search for efficiency can function as a way to gather more resources, as the Brazilian Ministry of Education (MEC) expressed its intent to increase the funding to the best-rated federal universities with respect to governance and innovation. MEC intends to revise the distribution model of resources between federal universities, forgoing the size of the institutions in favour of their performances (Fernandes and Tomazelli, 2019). The implementation of cost assessment and management, however, has long proved to be a difficult task for the federal universities, partially because of the heterogeneity of their activities: undergraduate programs, graduate lato-sensu and, stricto-sensu programs, and extension services (Peter et al., 2003; Medeiros and Duarte, 2018).

Cost management problems faced by higher education institutions are also found in international studies (Monteiro et al., 2015), who analysed the importance of management information stemming from cost accounting for European Public Higher Education Institutions, with emphasis on Portuguese universities. Under those circumstances, the following research question was raised: how are the recent cost assessment and implementation practices portrayed by the Brazilian federal universities? 
The objective of this research is, thus, to investigate the recent experiences of cost implementation and assessment on Brazilian federal universities, in face of a scenario of performance requirements and limited access to functionalities for cost assessment within the Integrated System for Financial Management (SIAFI). For a better understanding of the main objective of this research, the following specific objectives were established: identify the cost assessment stages in the Brazilian federal universities; determine the main challenges presented to these institutions regarding cost assessment; understand their main motivations to conduct cost assessment; and, analyse how these universities disclose their information on costs.

\section{THEORETICAL BACKGROUND}

\subsection{Public Administration Costs}

For Souza et al. (2011), cost planning and control support the decision-making process, highlighting the best conditions for good operational and financial performances. With respect to the public sector, Santos (2011) also uphold the importance of determining costs as a manner to gauge the performance of governmental programs, to overcome challenges and to provide social and political shifts.

Cost management can better direct the use of resources, without harming the quality of the services. In the public sector, there is a continuous demand for the expansion of services and for the quality of the expenses, since profitability is not a goal. Thus, the pursuit of financial control would be directed to an effective allocation of resources and to the improvement of an efficient distribution of public expenses (Bonacim and Araújo, 2010; Pereira and Silva, 2003).

\subsection{Costs in the Higher Education Institutions}

For Batista et al. (2017), the subject of costs in the public sector has a special characteristic for the HEFI. These institutions operate on a wide spectrum of education, research and extension activities, with a great diversity of activities. These authors exemplify some activities conducted in these institutions, such as: laboratory maintenance, university hospital management, museum maintenance, and book editing. The variety of their activities demonstrates the difficulty of establishing a system for cost assessment in these institutions.

Cost management in the public sector, notably in federal universities, is of great importance, since financial information may be used "for establishing standards, budgeting and expenses projections, and also to monitor whether the carried-out activities are in accordance with the pre-established values." (Magalhães et al., 2010, p. 639).

The main forms of expenditures of higher education institutions are: teaching costs, which include labour costs; research and extension costs; and, administration and maintenance costs. It is noteworthy the fact that this cost classification is applied to both public and private institutions in Brazil (Soares et al., 2009).

Cost assessment systems are useful management accounting tools for decision making. The implementation of those systems requires higher administration involvement, and the correct registration of movable assets depreciation and of material consumption. The registration of depreciation and material consumption, in the Brazilian HEFI, can be optimised by the adoption of the Integrated System of Services Administration (SIADS), an information system developed by the federal government, capable of migrating depreciation and material consumption cost information to SIAFI (Costa, 2016).

Santos (2017) mentions that cost assessment, from the perspective of cost of the programs and of the budgetary actions, raise a question regarding the criteria for cost allocation. According to the author, it is not objectively established that cost assessment should be based on the budgetary origins of the expenditure or on the realisation of an economic benefit. The conflict between the budgetary and patrimonial concepts is intertwined to the theme of expenditures in public administration and presents a challenge for the association of essentially patrimonial variables, such as depreciation and material consumption from inventories. 


\section{METHODOLOGY}

This is a qualitative, exploratory and descriptive research of previous experiences with cost assessment for Brazilian federal universities, stemming from documental analyses of management reports published on the website of the Brazilian Union Court of Accounts (TCU).

Out of the 68 universities by MEC, 63 reported to TCU by the means of their Management Report, pertaining to the year of 2018. 10 universities did not present any cost data in their reports, while 02 institutions did submit their Management Reports to TCU, however, as of September 8th, 2019, they were still under processing, which prevented its reading. In that regard, the current study was accomplished using costs information inserted on the reports of 51 universities, which characterized the sample of this study.

To achieve the established objectives for this study, the documental research was utilised. For the data analysis, the content analysis technique was chosen (Bardin, 2016). According to Chizzotti (2010), content analysis consists of correlating the recurrence of the quotations of some subjects, words or ideas in a text to measure the given relative importance to a certain topic by its author. The categorisation of the documents was done through the software Atlas.ti 7.0.

\section{RESULTS}

\subsection{Cost Assessment Stages}

Approximately $41 \%$ of those 51 institutions with information of the financial system, that is, 21 universities, while they include in their management report a passage on cost assessment, they inform that they have not embraced a cost assessment system yet.

The Federal Fluminense University (UFF), one of the institutions that have not established a cost assessment system, has declared, straightforwardly, it does not have a cost assessment system. A similar approach can be found in the management report of the Afro-Brazilian Lusophony Inclusion University (UNILAB), that states: "UNILAB does not have yet a cost assessment plan". In its turn, the Federal University of São João Del Rei (UFSJ), with no cost assessment system, acknowledges how important it is: "Cost Management is an important subject that is still not done systematically by the institution".

Three institutions, moving on, have already created in their organizational structure a dedicated unit to cost assessment and management. Those units are usually located in the sector responsible for planning and institutional evaluation of the university, as in the cases of the University of Brasília (UNB) and the Federal University of Grande Dourados (UFGD).

The Federal University of Rio Grande do Norte (UFRN), in its turn, has become a reference to other HEFI on cost assessment, with the establishment of a cost assessment template based on their value chain and a centre of cost coding to breakdown the costs of payments within SIAFI.

\subsection{Difficulties on Cost Assessment}

Putting cost assessment and management into practice has shown itself as an arduous assignment for HEFI. The difficulties related to ancillary information systems were the most quoted on the management reports, with 13 quotations. To assess cost, data that stems from several information systems are required. The challenge is to standardize and consolidate these data in the cost assessment task. Other difficulties presented were due to the internal environment (qualification of staff) with 4 citations and external (standardisation of cost objects) with 4 citations.

In the HEFI, the highest value expense is personnel. The cost data for personnel can be processed by the Federal Government Cost Information System (SIC), which is able to integrate the main systems of the Federal Government. The Personnel Management Integrated System (SIAPE) and the Organizational and Innovation Institutional System (SIORG) are two of these systems. Although, as the Federal University of Amazonas (UFAM) noted in its management report, "the correct feeding of personnel compensation data from SIAPE as well as of the updated management organizational chart from SIORG are necessary". 
The establishment of a cost assessment system and the resulting management, beyond providing information systems adjustments or substitutions utilised by universities, require arrangements related to the training of the staff involved in this task. The University of Rondônia (UNIR), for instance, acknowledges that "with some personnel reorganisation and training, a cost system should be implemented next year."

According the Resolution CFC No. 1366/2011, one of the cost information qualities is the comparability. It happens that, for the comparability to be achievable, it is necessary a standardized cost assessment methodology. In this context, the Federal University of Pará (UFPA) notes that "MEC has still not standardized cost assessment for Federal Universities".

The issues related to the physical structure of universities and to the data sharing between all layers within the institutions make cost assessment a difficult task. In that respect, the Federal University of Mato Grosso do Sul (UFMS) mentions: "to calculate the unit cost a student in UFMS courses, the main challenge for consolidating financial information is the apportionment of shared expenses in the College Town (Campo Grande/MS) and the information breakdown related to the staff payroll”.

\subsection{Motivations to Assess Costs in Federal Universities}

Magalhães et al. (2010) highlighted the importance of cost management in the public sector, notably in federal universities. The recent worsening of the budgetary and financial situation of these institutions has increased the urgency for them to become more efficient regarding their cost management. Thus, there are several reasons for the universities to implement a cost assessment and management system.

The compulsory filling of the cost centre on the payments tab within SIAFI and other cost accounting, such as depreciation, is recurrently cited in the management reports, with 16 quotations. STN plays a role in every federal government institution by making the filling of these accounting records in SIAFI mandatory. It has become possible to use the cost information recorded in SIAFI while incorporating the information from other supporting systems of the federal government. The Cost Information Manual of the Federal Government presents information regarding how public bodies can utilise the Business Intelligence (BI) Treasury tool to extract and organize cost data from several federal government cost systems (National Treasury Secretariat, 2018). In addition, the possibility of using cost information for decision making and increasing the efficiency of spending were also pointed as motivators for costing, with 6 and 3 citations, respectively.

In fact, the need to assess costs in federal universities also stems from a legal requirement. The Federal Rural University of Amazônia (UFRA) has an item in its management report that demonstrates the legal compliance of cost management in the public sector. In this item, the Fiscal Responsibility Law (LRF), the STN Ordinance No. 157/2011, the Federal Law 4.320/64 and the Federal Decree Law No. 200/1967 are mentioned. Therefore, it is made clear that cost assessment in federal universities is supported by legal imposition.

The Federal University of Alagoas (UFAL), for example, quotes a practical application of cost information, which consists of "knowing the expenses of developed projects, making it possible to claim compensation for indirect expenses of these projects". Accordingly, cost information, for example, is critical to a potential billing of lato-sensu postgraduate courses.

\subsection{Disclosure of Cost Information by Federal Universities}

Considering that the cost assessment task in Brazilian federal universities is relatively recent, an analysis of the quality of the disclosed cost information becomes relevant.

Universities often referred (with 13 citations) just to the costs website of the Brazilian federal government (http://www.tesourotransparente.gov.br/temas/contabilidade-e-custos/sistema-de-custos) when presenting cost information in their management reports. This website has open access for the public and allows access to interactive panels with information stemming from the combination of data from the supporting systems of the federal government (National Treasury Secretariat, 2019).

The Federal University of Roraima (UFRR), for example, informed, through its management report, that "the cost assessment task of this institution is being conducted utilizing the Federal Government's website. The website is a project developed by the Cost Information Department of the National Treasury Public Accounting Bureau". Making cost information available through open access is important as a transparency 
initiative. However, this kind of information is not relevant for use as a subsidy for decision-making since it does not take into account the specific information needs from the universities.

Some universities (with 6 citations) even reported budgetary figures as in they were cost figures, demonstrating their limited knowledge about the required adjustments between those figures (Machado and Holanda, 2010).

\section{CONCLUSION}

The analysis of the management reports released by Brazilian federal universities revealed that, of the 61 documents acquired on the TCU website, 10 did not contain information on cost assessment. In addition, 21 universities informed that they have not adopted any cost assessment system, despite including in their management reports passages on cost assessment.

Regarding current cost assessment stages, heterogeneous situations were found. While some institutions, despite recognizing the importance of cost assessment, remain at the research stage to define a methodology, others have already decided on one. UFRN, for example, moved ahead and defined a coding to be utilised on the process of data feeding in the SIAFI, becoming a reference to other universities in this regard.

As to the difficulties related to the implementation of cost assessment and management, the inadequacy of supporting information systems and the lack of a defined cost methodology from MEC have been emphasized.

The compulsory filling of the cost centre on the SIAFI expenses payments tab, established by STN during the year of 2018, has appeared as a relevant event to motivate the universities to implement measures to assess and manage costs. It is worth mentioning that the necessity to assess and manage costs within the scope of the Brazilian federal public administration also results from a legal requirement and is essential to subsidize the public manager's decision making.

Some initiatives from universities related to the disclosure of cost information were identified, primarily on the costs website of the federal government. Such initiative can be considered a positive factor with regard to transparency. Nonetheless, the information disclosed in this website has limited use for decision making.

The results found by this study alert to the necessity to establish a methodology that includes a minimal standard to assess costs in the federal universities. A defined standard will make the comparison of costs between institutions possible, the identification of successful practices in the cost management and the use of cost information as a measure of efficiency, efficacy and effectiveness of the universities' management.

The universities must observe the fact that STN made available for them tools to assist with cost assessment, which became relevant due to the compulsory filing of the cost centre tab and the federal government financial costs manual release. These tools consider the importance of gathering information from the federal government's supporting systems.

It is suggested for future researches that the study is reapplied shortly, since numerous ongoing cost assessments initiatives were identified among HEFI. Another suggestion to approach the theme is the realisation of in-depth studies in universities that have already made substantial progresses on the task of cost assessment, in order to capture detailed aspects of cost assessment not revealed in the management reports. Other government bodies in the federal, state and municipal levels can also benefit from the HEFI's experience with the implementation of cost assessment.

\section{REFERENCES}

Bardin, 2016. Análise de conteúdo. Edições 70, São Paulo.

Batista, A. P. et al, 2017. Custeio Baseado em Atividades no Serviço Público: um Estudo de Caso na Universidade Federal do Rio de Janeiro. In Anais do Congresso Brasileiro de Custos-ABC.

Bonacim, C. A. G., and de Araujo, A. M. P., 2010. Gestão de custos aplicada a hospitais universitários públicos: a experiência do Hospital das Clínicas da Faculdade de Medicina de Ribeirão Preto da USP. Revista de Administração Pública, 44(4), 903-931.

Chizzotti, A., 2010. Pesquisa qualitativa em ciências humanas e sociais. Vozes, Petrópolis. 
Costa, F. T. D., Jr., 2016. Gestão de custos no setor público: análise da viabilidade de implantação do sistema de informações de custo do Governo Federal (SIC) no Instituto Federal de Educação, Ciência e Tecnologia da Paraíba (IFPB). Master's thesis, Universidade Federal do Rio Grande do Norte.

De Souza, E. X. et al, 2011. Implantação de um Sistema de Custos no Setor Público: um Estudo de Caso em um Hospital de Ensino do Nordeste Brasileiro. VIII SEGeT-Simpósio de Excelência em Gestão e Tecnologia-2011. Retrieved from https://www.aedb.br/seget/arquivos/artigos11/48414591.pdf

Fernandes, A., Tomazelli, I., 2019. MEC estuda mudar distribuição de recursos para universidades federais. O Estado de São Paulo. August, 19, 2019. Retrieved from https://educacao.estadao.com.br/noticias/geral,mec-estuda-mudardistribuicao-de-recursos-para-universidades-federais, 70002973204.

Machado, N. and Holanda, V. B. D., 2010. Guidelines and conceptual model of costs for the public sector based on the Brazilian federal government's experience. Revista de Administração Pública, 44(4), 791-820.

Magalhães, E. A. D. et al, 2010. Custo do ensino de graduação em instituições federais de ensino superior: o caso da Universidade Federal de Viçosa. Revista de Administração Pública, 44(3), 637-666.

Medeiros, A. L. and Duarte, M. M. T., 2018. Modelo de apuração de custos em universidades federais. Revista Observatório, 4(5), 813-848.

Monteiro, R. P. et al, 2015. A necessidade da informação gerencial nas IES públicas da Europa: breve abordagem pela realidade de Portugal. Revista Catarinense da Ciência Contábil, 14(42), 9-24.

Pereira, J. R. T. and da Silva, A. C., 2003. A Importância da Implantação de Sistema de Custos para a Gestão do Setor Público. In Anais do Congresso Brasileiro de Custos-ABC.

Peter, M. D. G. A. et al, 2003. Proposta de um sistema de custos para as universidades federais brasileiras fundamentado no activity based costing. Encontro Nacional dos Programas de Pós-Graduação em Administração.

Portaria n. 157, de 9 de março de 2011, 2011. Dispõe sobre a criação do Sistema de Custos do Governo Federal. Retrieved from http://www.fazenda.gov.br/pmimf/frentes-de-atuacao/custos/download-dearquivos/portstn_157_09mar2011.pdf.

Santos, R. B., 2017. Custos no serviço público federal: uma análise dos modelos de apuração aplicáveis às universidades federais brasileiras. Master's thesis, Graduate Program in Controllership, Universidade Federal Rural de Pernambuco, Pernambuco, PE, Brasil.

Santos, W. V. D., 2011. Sistema de informação de custos do Governo Federal: Modelo conceitual, solução tecnológica e gestão do sistema. Anais do Congresso CONSAD de Gestão Pública, Brasília, DF, Brazil.

Secretaria do Tesouro Nacional, 2018. Manual de Informações de Custos do Governo Federal. Retrieved from http://www.tesouro.fazenda.gov.br/-/manuais-de-custos

Secretaria do Tesouro Nacional, 2019. Tesouro Transparente - Sistema de Custos. Brasília: Secretaria do Tesouro Nacional. Retrieved from https://www.tesourotransparente.gov.br/temas/contabilidade-e-custos/sistema-de-custos.

Soares, T. et al, 2009. Modelagem de estrutura de custos em Instituição de Ensino Superior. Revista de Administração, Contabilidade e Economia, 8, 267-290. 